\title{
The Using Results of OER Mobile Application to Enhance 21st Century Skills in Information Media and Technology Skills for Humanities and Social Sciences
}

\author{
https://doi.org/10.3991/ijim.v14i19.17105 \\ Kemmanat Mingsiritham \\ Sukhothai Thammathirat Open University, Nonthaburi, Thailand \\ Prakob Koraneekij (四) \\ Chulalongkorn University, Bangkok, Thailand \\ prakob.k@chula.ac.th
}

\begin{abstract}
Mobile technology has been utilized by educational institutions, especially in a higher education level, to enhance teaching and learning. It is a tool to support learning by motivating and learners to become interested and engaging. Open Education Resource (OER) provides a reliable source of information and learning resources that learners can access free of charge. However, learners must be ready to use information technology in order to fully access learning resources. This paper will discuss information media and technology skills of 33 Thai students studying Humanities and Social Sciences in autonomous universities from OER Mobile Application. Students' skills were assessed through self-assessment and behavior and performance observation. The research results indicated that students' skills were improved gradually.
\end{abstract}

Keywords-Application, Mobile Learning, Open learning, Information Media and Technology skills

\section{Introduction}

Mobile learning is mainly in the form of smart mobile devices (smartphones and tablets). It has gained popularity in higher education as it expands the possibilities of learning outside the classroom [1], [2]. Major factors that make mobile learning become the trend in higher education globally are the advancement of mobile technology over the past ten years, widely accessibility of mobile devices, and the availability of the internet [3], [4]. Higher education learners view that mobile learning makes learning more accessible and convenient. Mobile technology consists of various applications and tools that enable learners to access learning outside the classroom and have interaction with learning processes [5]. Mobile learning in higher education institutes increases student and instructor collaboration, makes students become more engage in learning, and creates learning communities. It has become an innovative learning approach, making learning more enjoyable and flexible [2], [6]. An important 
challenge in integrating learning with mobile devices is to ensure that students have the ability to use technology and media for the utmost benefit, have the responsibility in using technology, can analyze information critically, and use technology to solve challenging new problems. Therefore, teachers need to integrate the Open Education Resource, which is a large knowledge database for learners to provide learning opportunities for everyone. Students can acquire knowledge to apply and to solve new challenges creatively. This kind of learning enables students to practice thinking skills and the sharing of knowledge. It promotes learning throughout life, leading to meaningful learning. This research examines the development of students' information media and technology skills by using OER mobile application. Behavior observation during activities and work assignments of students were examined. The research results provide the development of a learning process that can be used in education.

\section{Review of the Literature}

Mobile learning has become the new era of e-Learning. It has contributed to delivering education, especially in higher education level globally. Even though the adoption of mobile learning is widely among developed countries, the use of mobile learning in developing countries is still at the beginning stage with several challenges [7], [8].

The availability of mobile devices and internet has made mobile learning wildly adopted in higher education institutes. Access to learning content and information is convenient and can occur anywhere and anytime. [9] The difference between personal computers and mobile devices is portable features. M-learning is a mobile learning platform available on smartphones and tablets, enabling learners to learn anywhere, anytime. It is accessible to a large number of users, even in remote areas with the internet network [10], [11]. Mobile devices offer a number of advantageous features such as SMS, voice mail, audio and video recorders, cameras, games, and various applications. These features enable a variety of multimedia materials to be delivered through learning platform which can provide more diverse learning inside and outside classroom [12], [13]. The study of the benefits of using mobile learning shows that one of the major advantages of using mobile learning is student-centered learning. Students can share ideas and perspectives for learning new things [14], [15] as it introduces educators and learners to new ideas that they cannot observe directly [16]. Combining mobile learning with open learning resources, such as online media, ebooks, video clips will enable students to choose to learn freely and share knowledge, resulting in a new learning experience and a learning community.

\section{Research Methodology}

This research studied the development of information media and technology skills by using OER mobile application of 33 students studying in the autonomous universities in Humanities and Social Sciences. The research participation was voluntary 
basis. The researcher followed privacy can confidentiality policy. Research participants' identities remained unidentifiable.

\subsection{Design}

To develop OER mobile application, the researchers studied, analyzed and synthesized concepts, theories, and research related to mobile application design, virtual open classroom system, open learning resources, and learning skills in the 21 st century in information media and technology skills. Then, the structure of the OER mobile application was developed as an application that runs on Android devices which links to OER and social networks. It has 5 important features as follows.

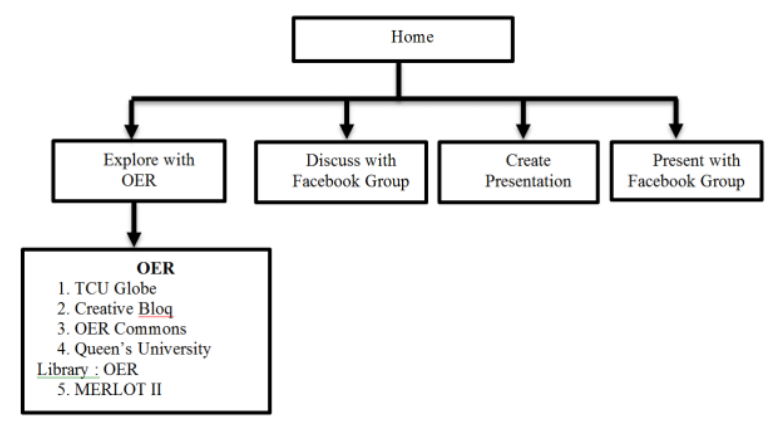

Fig. 1. Structure of OER mobile application
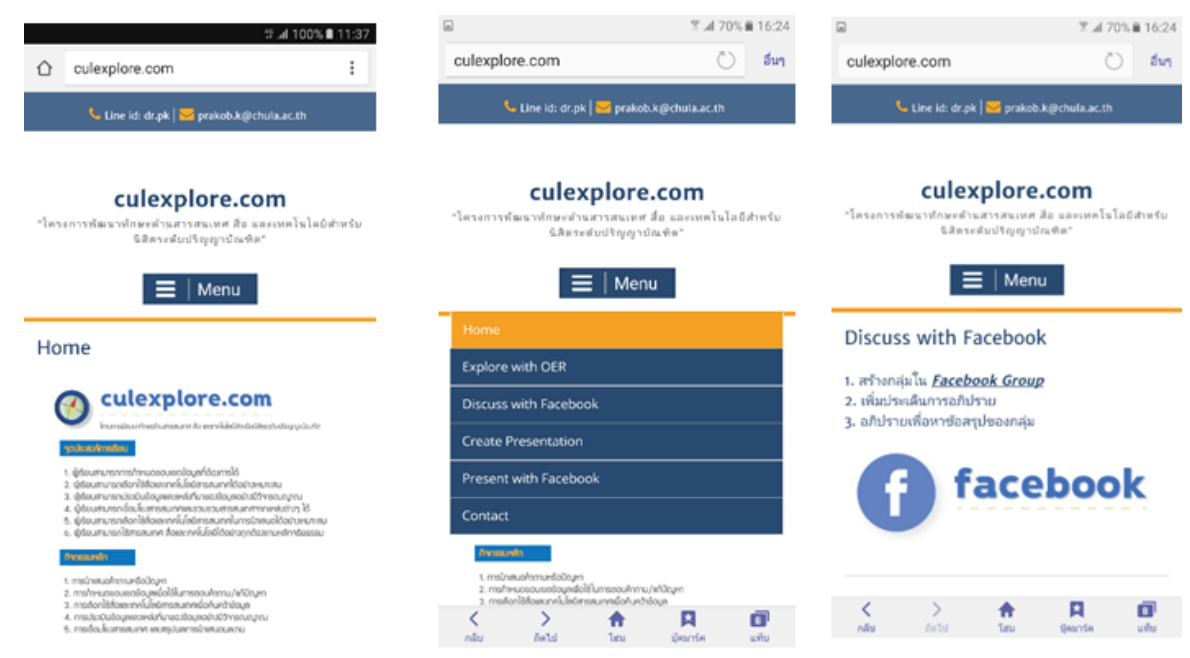

Fig. 2. OER Mobile Application 


\subsection{Research instruments}

The tools used were 1) self-assessment form before and after studying in the form of a 5-level assessment scale with Item Objective Congruence equal to $0.89,2$ ) behavior observation form assessed by the instructor after studying in the form of a 5-level assessment scale with Item Objective Congruence equal to 0.94, and 3) assignment evaluation form assessed by the instructor during the study in the form of 3-level rubric assessment criteria with Item Objective Congruence equal to 1.00 .

\subsection{Research method}

The researchers provided an orientation for students about using OER mobile application that focuses on information media and technology skills and learning activities. Students learned to use educational support tools. The researchers carried out activities according to the learning guidelines using OER mobile application developed. Before the activity, the sample group did the self-assessment. During the experiment, the researchers assessed the development of information media and technology skills by using the assignment evaluation form in the 2nd, 4th, and 6th activities and the behavior observation form of the sample group, after completing the experiment, the sample did the self-assessment after studying.

\subsection{Data analysis}

1. Comparing self-assessment before and after studying by using dependent t-test statistics.

2. Basic statistical analysis of scores for assessment of learning behavior with OER mobile application.

3. One-way repeated measure analysis in one case of the sample group to compare the work of the sample during different periods (week 2, week 4 and week 6).

\section{$4 \quad$ Research Findings}

1. The results of the comparison of information media and technology skills before and after the experiment found that before studying, the sample group had average scores of information media and technology skills at 3.44 and standard deviation at .29. After the study, the sample group had average scores of information media and technology skills at 4.46 and standard deviation at .26 . The test of the difference of the average scores in information media and technology skills before and after studying by using dependent t-test statistics found that average scores after studying were higher than before studying with the statistical significance at level of .05 $(\mathrm{t}=17.382, \mathrm{p}=.000)$ as shown in Table 1. 
Table 1. Comparison results of the ability of information media and technology skills before and after studying

\begin{tabular}{|l|c|c|c|c|c|}
\hline & n & Mean & SD & t & p \\
\hline Pretest & 33 & 3.44 & .29 & \multirow{2}{*}{17.382} & \multirow{2}{*}{$0.000^{*}$} \\
\hline Posttest & 33 & 4.46 & .26 & & \\
\hline
\end{tabular}

2. Evaluation results of learning behavior with OER mobile application found that students had learning behavior at a very high level $(\mathrm{M}=4.52$, S.D. $=.26)$. When considering each item, it was found that the correct and ethical use of information, media and technology $(\mathrm{M}=4.59, \mathrm{SD}=.33)$ had the highest mean, followed by media and information technology selection $(\mathrm{M}=4.53, \mathrm{SD}=.35)$ and data area setting $(\mathrm{M}=4.52, \mathrm{SD}=.32)$ respectively.

3. Results of one-way repeated measure analysis of assignment evaluation by learning with OER mobile application found that there was statistical significance at the level of .05. This means that each period (week 2, week 4, week 6) students had different scores with statistical significance at the level of .05. The results of post hoc tests showed that there were 3 pairs of statistically significant differences. The evaluation results in week 6 were higher than those in week 2 and week 4 . The evaluation results in week 4 were higher than those in the week 2 as shown in Table 2 .

Table 2. Results of one way repeated measure analysis of assignment evaluation

\begin{tabular}{|l|c|c|c|c|c|c|}
\hline $\begin{array}{c}\text { Source of } \\
\text { Variance }\end{array}$ & SS & df & MS & F & p & Post Hoc Analysis \\
\hline Time & 2.283 & 1.272 & 1.795 & 96.953 & .000 & \multirow{2}{*}{$2<4,2<6,4<6$} \\
\cline { 1 - 5 } Within cell & .754 & 40.714 & .019 & & & \\
\hline
\end{tabular}

\section{$5 \quad$ Discussion and Conclusion}

Students' learning and collaboration have been improved evident by the score of information media and technology skills. This may be due to the fact that students are familiar with mobile learning. Continuous use of mobile learning has created a positive attitude, resulting in the development of skills. Collaboration and sharing of information can occur effectively without feeling that it is a barrier to learning. This is consistent with [17] stating that mobile learning has become an important educational technology component in higher education. Mobile learning enables students to learn, collaborate, and exchange knowledge and ideas through the use of the internet and technology. Activities and presentations on social media are popular among higher education learners. Using familiar applications makes communicating on social media quick and easy. This enables students to make use of skills and knowledge and cooperate well. In [18] studying the recognition of m-learning as an important assistive technology. The selection of technology that the students are familiar with and respond to their needs will make them see the benefits of m-learning as a learning enhancement tool in which students are more likely to cooperate. Similarly. In [19] 
shows that easy-to-use technology has a positive influence on m-learning acceptance. Learners perceive that m-learning is convenient to use for learning. However, when conducting activities via the OER mobile application, teachers have to be a facilitator and prepare reliable learning resources, and provide information searching channels. For effective learning, learning resources should be constantly updated to provide teachers and learners with up-to-date knowledge. Learning design should be userfriendly and use technology that most learners are familiar with.

\section{Acknowledgement}

This research was supported the scholar from National Research Council of Thailand and The Thailand Research Fund.

\section{$7 \quad$ References}

[1] Crompton, H. \& Burke, D. (2018). The use of mobile learning in higher education: A systematic review. Computer \& Education. 123(August 2018), 53-64 pp. https://doi.org/10.10 16/j.compedu.2018.04.007

[2] Kalisa, R. \& Picard, M. (2017). A systematic review on mobile learning in higher education: The african perspective. Tojet: The Turkish Online Journal of Educational Technology. 16(1)(January 2017), 1-8 pp.

[3] Shorfuzzaman, M., \& Alhussein, M. (2016). Modeling learners' readiness to adopt mobile learning: A perspective from a GCC higher education institution. Mobile Information Systems, 1(1), 1-10 pp. https://doi.org/10.1155/2016/6982824

[4] Godfrey, I. M., Calkin, S. M., Esther, R. M., \& Solomon, S. O. (2020). Demonstration of a mobile education artifact in a Tanzania's higher education institution. International Journal of Interactive Mobile Technologies. 14(14), 31-50 pp. https://doi.org/10.3991/ijim.v14i14. $\underline{13195}$

[5] Callum, K., Jeffrey, L., \& Kinshuk, I. (2014). Factors impacting teachers' adoption of mobile learning. Journal of Information Technology Education: Research, 13(1), 141-162 pp. https://doi.org/10.28945/1970

[6] Bartholomew, S. R., Reeve, E., Veon, R., Goodridge, W., Lee, V. R., Nadelson, L. (2017). Relationships between access to mobile devices, student self-directed learning, and achievement. Journal of Technology Education. 29, 2-24 pp. https://doi.org/10.21061/jte.v 29i1.a.1

[7] Ahmad, S. A., Amr, A. M., \& Zahra, Z. (2018). Modeling students' Readiness to adopt mobile learning in higher education: An empirical study. International Review of Research in Open and Distributed Learning. 19(1)(February 2018). 221-241 pp. https://doi.org/10.19 173/irrodl.v19i1.3256

[8] Hazah, W. M., Yusoff, M. H., Ismail, I., \& Yacob, A. (2020). The behavioral intentions of secondary school students to use tablet as a mobile learning device. International Journal of Interactive Mobile Technologies. 14(13), 161-171 pp. https://doi.org/10.3991/ijim. v14i13.13027

[9] Claudia, D. W., \& Gloerfeld, C. (2017). Mobile learning and higher education. The Digital Turn in Higher Education. 61-77 pp. https://doi.org/10.1007/978-3-658-19925-8_6 
[10] Al-Adwan, A. S., Al-Adwan, A., Berger, H. (2018). Solving the mystery of mobile learning adoption in higher education. International Journal of Mobile Communications. 16, 2449 pp. https://doi.org/10.1504/IJMC.2018.088271

[11] Buckner, E., Kim, P. (2012). Mobile innovations, executive functions, and educational developments in conflict zones: A case study from Palestine. Educational Technology Research and Development. 60, 175-192 pp. https://doi.org/10.1007/s11423-011-9221-6

[12] Churchill, D., Fox, B., King, M. (2016). Framework for designing mobile learning environments. In Churchill, D., Lu, J., Chiu, T., Fox, B. (Eds.), Mobile learning design (3-25 pp). Singapore: Springer. https://doi.org/10.1007/978-981-10-0027-0_1

[13] Wong, L.-H., Looi, C.-K. (2011). What seams do we remove in mobile- assisted seamless learning? A critical review of the literature. Computers \& Education. 57, 2364-2381 pp. https://doi.org/10.1016/j.compedu.2011.06.007

[14] Fu, Q.-K., Hwang, G.-J. (2018). Trends in mobile technology-supported collaborative learning: A systematic review of journal publications from 2007 to 2016. Computers \& Education. 119, 129-143 pp. https://doi.org/10.1016/j.compedu.2018.01.004

[15] Alkhunzain, A. S. (2019). An empirical study on smartphone addiction of the university students. International Journal of Interactive Mobile Technologies. 13(12), 184-195 pp. https://doi.org/10.3991/ijim.v13i12.11120

[16] Abu-al-aish, A., \& Love, S. (2013). Factors influencing students' acceptance of Mlearning: An investigation in higher education. The International Review of Research in Open and Distance Learning, 14(5), 83-108 pp. https://doi.org/10.19173/irrodl.v14i5.1631

[17] Papadakis, S., Kalogiannakis, M. and Zaranis, N. (2018). Educational apps from the android Google play for Greek preschoolers: a systematic review. Computer \& Education. 116, 139-160 pp. https://doi.org/10.1016/j.compedu.2017.09.007

[18] Mostafa, A. E., Hatem, M. E., \& Khaled. S. (2016). Investigating attitudes towards the use of mobile learning in higher education. Computers in Human Behavior. 56(March 2016), 93-102 pp. https://doi.org/10.1016/j.chb.2015.11.033

[19] Masrek, M. N. (2015. May 12th - 15th). Predictors of mobile learning adoption: The case of Universiti Teknologi MARA. In Proceedings of the 7th International Conference on Information Technology (ICIT), Jordan

\section{Authors}

Kemmanat Mingsiritham is an Associate Professor at the Office of Educational Technology, Sukhothai Thammathirat Open University, Nonthaburi 11120 Thailand. Her Research interests include Instructonal Design, Virtual Learning Design, and Distance Learning. (kemmanat.min@stou.ac.th)

Prakob Koraneekij is an Associate Professor at the Department of Educational Technology and Communications, Faculty of Education and Educational Invention and Innovation Research Unit, Chulalongkorn University, Bangkok, Thailand. His research interests include E-Portfolio, Mobile Learning, Blended Learning, and MOOCs. (prakob.k@chula.ac.th)

Article submitted 2020-07-17. Resubmitted 2020-09-11. Final acceptance 2020-09-11. Final version published as submitted by the authors. 